\title{
El primer Manierismo toscano y P. P. Pasolini
}

Para Carmen Gaitán

En memoria de Federico Campbell

El Manierismo nace en Toscana en los años 20 del siglo XVI, después de la aparición fulgurante de los tres grandes astros - Rafael, Leonardo y Miguel Ángel-, que con su obra creativa cierran el pleno Renacimiento. Leonardo muere en 1519, Rafael en 1520, y Miguel Ángel continuará laborando en las obras para los Médici, hasta su muerte en 1564, a los 89 años. Con ellos el Renacimiento ha dado todo de sí. De hecho, las últimas obras de Rafael y Miguel Ángel contienen los gérmenes de la disolución y están llenas de fermentos anticlásicos. Miguel Ángel, como se sabe, anticipa ya el Barroco en la cúpula de la Basílica de San Pedro en Roma, en la Piedad Rondanini (Milán, Castillo Sforzesco) y en la Biblioteca Laurenciana de Florencia.

Y es con Miguel Ángel que se rompen las estructuras clásicas y empieza la tensión barroca, la convulsión de las líneas, el movimiento desaforado que es su signo, la aglomeración de figuras y objetos en movimiento, lo "relleno" que oculta el miedo del vacío, el horror vacui. Lo no acabado, lo ilimitado que aparece en las últimas esculturas del reformista Miguel Ángel, está en directa relación con la inquietud religiosa, con la sed de infinito y el misterio de la Gracia que lo atormentan. La problemática relación entre el hombre y Dios (presente en el Juicio final de la Capilla Sixtina), el anhelo de una idea inalcanzable y el misterio de la muerte; en pocas palabras, su visión trágica que, según Lucien Goldmann, lo une a Racine, Pascal y Kant, no puede conciliarse 
con la medida renacentista. Viene al caso recordar la tesis de Heinrich Wölfflin, de la disolución del Renacimiento en el Barroco y también la imagen del francés Jean Rousset: “¿Qué es una fachada barroca? Es una arquitectura del Renacimiento reflejada en el agua, más aún, su imagen en una agua inquieta".

Los jóvenes artistas que después de los tres grandes inician el movimiento que Giorgio Vasari llamará Manierismo — de "maniera", palabra que él usa como sinónimo de estilo, es decir, la manera de expresarse del artista-, son florentinos: Andrea del Sarto, Jacopo da Pontormo (Jacopo Carruggi), su más joven y amado discípulo Bronzino (15031575) y Rojo Florentino (Rosso Fiorentino), a los que se unirá Giorgio Vasari, toscano nacido en Arezzo en 1511, autor de Vidas de los más excelentes arquitectos, pintores y escultores italianos desde Cimabue hasta nuestros dias, fuente importante para conocer a los artistas italianos hasta el Renacimiento y el Manierismo.

Pontormo y Rojo Florentino - que tendrán una gran influencia en P. P. Pasolini- nacen ambos en 1494, en ese último e inquieto decenio del siglo Xv, que vivió acontecimientos decisivos para el mundo occidental: el descubrimiento de América en 1492, inicio de la Edad Moderna y del execrable colonialismo europeo. Paralela al descubrimiento, la larga crisis espiritual, política y social que se había prolongado en Florencia a lo largo de la segunda mitad del siglo xv, explota en una catástrofe que se extenderá en el siglo siguiente a toda Italia, hecha teatro de las guerras sangrientas de Francia y España por el dominio de la península. La crisis se inicia a causa de la transformación política de Florencia, por obra del astuto y corrupto Cosme de Médici que, "dotado de una inteligencia fuera de lo común" (Raymond Aron), logró convertir la República florentina en Señoría hereditaria; lo que significó un parteaguas entre la primera y la segunda mitad del siglo del Humanismo. Su hijo Lorenzo el Magnífico, que vive en su corte con lujo desenfrenado, rodeado por una corte de poetas, literatos y artistas, reforzará el poder de la dinastía Médici. La polémica en contra de la tiranía seguirá inflamada pero inane. La libertad exigida será ahogada en sangre durante la fallida Congiura dei Pazzi (1478) contra los Médici, por el mismo pueblo que, al grito de "iViva la libertad!" de los opositores, contesta: "¡Viva Lorenzo que nos da el pan!” 
En el clima de desánimo, impotencia y opresión generado por la supresión de la libertad - "en una ciudad como Florencia acostumbrada desde siempre a ser libre" (Maquiavelo) - , nace un fuerte sentimiento de muerte, de destrucción (en contraste con el anhelo de renovatio y las expectativas escatológicas que acompañaron la tristeza de ocaso de esos decenios), que provocó el repliegue de la inteligencia ciudadana y su alejamiento de la vida política, que inicia en los años treinta con el tratado De familia de L. B. Alberti. A la participación activa que había caracterizado los primeros años luminosos y llenos de entusiasmo creativo del Humanismo florentino, sigue el pesimismo y un sentimiento de muerte y de destrucción presente en las artes figurativas, en el Apocalipsis de la Catedral de Orvieto del umbro Luca Signorelli, cuya pintura gravita en la órbita florentina; presente también en los grabados sobre el Apocalipsis de Durero y en Leonardo, que alterna proyectos de nuevas máquinas y ciudades con imágenes de destrucción universal.

La segunda mitad del siglo del Humanismo está llena de obscuros presagios para el futuro de Italia y concluye en un decenio de acontecimientos trágicos. Veamos: en 1492 muere Lorenzo de Médici, tirano pero hábil diplomático que, con su sagaz política, había logrado mantener durante cuarenta años la paz pactada por el Tratado de Lodi en 1454. Con su muerte el tratado se volverá letra muerta. En 1494 Carlos VIII entra a Florencia sin encontrar resistencia, "sin — dice Montaigne - ni siquiera desenvainar la espada de su funda". Es el inicio de la intromisión extranjera en Italia y de la pérdida de la independencia de la península. En ese mismo año, Girolamo Savonarola, "el Lutero italiano" alrededor del cual se aglutinan artistas, poetas y filósofos (Botticelli, Miguel Ángel, Pico della Mirandola, para nombrar los más conocidos) logra, con sus predicaciones en contra de la tiranía medicea, de la corrupción y del lujo desenfrenado de su corte, levantar al pueblo florentino que expulsa de la ciudad a los Médici. Se declara la república popular a favor de una reforma religiosa y de una moralización de las costumbres, reforma que conoció excesos de fanatismo religioso. Son los años en que se asoma a la escena política Nicolás Maquiavelo, quien va a San Marcos a escuchar, entre admirado y escéptico, al "profeta desarmado" que en 1498 será apresado, torturado durante 42 días, y luego ahorcado y quemado en la Plaza de la Señoría. 
Hijos de la crisis espiritual del Humanismo, Pontormo y Rojo Florentino harán su formación en las primeras décadas del infeliz siglo del pleno Renacimiento, sacudido por las guerras religiosas y los graves acontecimientos que rompieron el ya precario equilibrio del mundo europeo. Antes que nada, la revolución heliocéntrica del polaco Nicolás Copérnico - presentada como hipótesis por miedo a la Inquisiciónque desplaza al hombre de su centralidad. El hombre cae del pedestal en el que lo había puesto Pico della Mirandola. De la estabilidad clásica, del mundo cerrado se pasa al mundo infinito, y el infinito genera asombro, miedo y vértigo. En el siglo siguiente Pascal, que sentía el peso del mundo físico, escribirá: "Los silencios de estos espacios infinitos me aterran". En un corto escrito, "La esfera de Pascal", J.L. Borges nos hace revivir el horror de Pascal ante el infinito: "Es obvio [escribe Borges] que un sentimiento de susto y de espanto tuvo que asaltar al hombre ante el espacio infinito. Es un vértigo del que quiere deshacerse moviéndose". A la revolución heliocéntrica seguirá inmediatamente otra revolución, la de Maquiavelo. En 1513 escribe El Príncipe, que derrumba el mito de la política subordinada a la ética, es decir, que decide la demarcación definitiva entre la ética y la política que todavía nos agobia: la política como actividad autónoma más allá del bien y del mal, con sus leyes propias y con su ética propia. El florentino desenmascaró definitivamente la realidad del quehacer político y el drama del poder que Shakespeare llevará al teatro. Para las conciencias europeas, como dice Friedrich Meinecke, la separación entre ética y política fue como "una espada que se clavó en el cuerpo de la humanidad haciéndola gritar y rebelarse". En ese mismo decenio Martín Lutero da inicio a la Reforma que terminará por romper la unidad religiosa del continente europeo. Seguirá, en 1527, el Saqueo de Roma, el más terrible de los saqueos que haya sufrido a lo largo de su historia, por el ejército (diez mil españoles y diez mil lansquenetes enemigos de la corrupta capital de la Iglesia), que Carlos envía para vengarse del papa Clemente VII que se había adherido a la Liga de Cognac en su contra. El ejército se dedicó, a hierro y fuego, a la masacre y a la destrucción de la ciudad, dejándola en sólo ocho días en ruinas, y a su población diezmada. La profanación de la ciudad eterna, símbolo de la cristiandad, conmovió y sacudió a toda Europa. 
Quizá insisto demasiado en el contexto histórico de esas décadas, pero es de ese mundo en convulsión que nace la nueva atormentada y "bizarra" generación de los manieristas, situada, como dice el insigne Mario Praz, entre la fase apolínea del Renacimiento y la dionisíaca del Barroco. Con ella empieza un largo período de transición y de experimentación que concluirá en el Barroco: una pausa de reflexión y de ahondamiento psicológico, una nueva sensibilidad intensa y refinada que se refleja en los retratos pensativos que parecen dar un adiós al mundo aristocrático de El Cortesano de Baldassarre Castiglione. Doy un rápido ejemplo de tres cuadros: "El alabardero" de Pontormo $(92 \mathrm{x}$ $72 \mathrm{~cm}$, Cambridge, Massachusetts, Fogg Art Museum); el "Retrato de Ugolino Martelli" de Bronzino (96 x 68 cm, Washington, National Gallery of Art) y el "Retrato de joven" de Rojo Florentino $(88.7$ x $67.9 \mathrm{~cm}$, National Gallery of Art, Washington).

Los tres artistas, al rechazar el clasicismo ya en crisis, toman el camino de la innovación en la búsqueda afanosa de un estilo personal. Habían trabajado en varios talleres, entre los cuales está la bottega del “extravagante y misántropo" Piero di Cosimo (de quien Vasari deja un estupendo retrato) y parecen haber sido contagiados por la compleja personalidad del gran maestro, pero es la inquietud de su tiempo la que heredan, y una necesidad de silencio en el tumulto de los acontecimientos del nuevo siglo, que Miguel Ángel expresa en un doloroso soneto:

Grato me es el sueño, y más el ser de piedra, / mientras que el daño y la vergüenza duran; / no ver, no sentir me es gran ventura; / no me despiertes, no; habla bajo ${ }^{1}$ (La traducción es mía).

Inquietos, introvertidos y solitarios, los tres se aislarán como Piero di Cosimo y Miguel Ángel en el mundo del arte. Pontormo se encierra en su casa, que no es por cierto el tugurio donde vivía Piero di Cosimo, en medio de la inmundicia (y jay de quien quisiera limpiarla!). Narra Giorgio Vasari en sus Vidas que Pontormo se encerraba en su recámara subiendo por una escalera que luego retiraba para que nadie subiera a

1 Caro m'è il sonno e più l'esser di sasso, / mentre che'l danno e la vergogna dura; / non veder, non sentir m'è gran ventura / Però non mi destar; deh, parla basso. 
molestarlo. De la atormentada personalidad de Pontormo y de su eterna insatisfacción Vasari dice: "Se atormentaba tanto el cerebro que daba compasión, borrando y rehaciendo hoy lo que había hecho ayer". El diario que Pontormo escribe en sus últimos tres años de vida es un documento importante para conocer al genial hipocondríaco, aislado de la realidad que rechazaba. Según Max Dvořák, el Manierismo es la primera manifestación de la separación entre real e ideal presente en la figura trágica y cómica de don Quijote.

Del genio de los manieristas, sus contemporáneos no se dieron cuenta. Considerado más bien como amaneramiento, imitación de los tres grandes y decadencia del Renacimiento, el Manierismo caerá pronto en un olvido que durará siglos hasta ser redescubierto y evaluado en la primera mitad del siglo xx, en el que serán subrayadas sus afinidades con el nuevo tiempo: desarraigo del intelectual, pérdida de los valores sociales, crisis política y religiosa, etcétera. Entre los estudiosos del siglo XVI (Cinquecento) se encuentra el gran historiador del arte Roberto Longhi, catedrático en la Universidad de Bolonia desde 1934. A sus lecciones se presenta, en 1939, P.P. Pasolini, matriculado en Filosofía y Letras. "Para un muchacho oprimido [escribirá Pier Paolo] por la cultura escolar, por el conformismo de la sociedad fascista, ésta fue la revolución". El encuentro con Longhi fue una "fulguración figurativa", como él la llama. Al maestro y luego amigo, quedará ligado por una auténtica veneración que manifiesta en 1962, dedicándole su película Mamma Roma.

En Bolonia, a la pasión por el deporte, Pasolini une la pasión por las imágenes. Empieza a dibujar usando técnicas y materiales heterodoxos, y proyecta volverse pintor (es interesante notar que su predisposición a la pintura se manifiesta en la temprana edad de siete años, cuando empieza a ilustrar su diario). En esos años escribe artículos sobre Carrà, De Pisis, Morandi, entre otros pintores. Elige la pintura contemporánea como tema de tesis de licenciatura, bajo la dirección de Longhi, a la que tuvo que renunciar a causa de la guerra (se recibirá con una tesis sobre el poeta Giovanni Pascoli, que mereció la summa cum laude).

La guerra y los bombardeos en Bolonia obligaron a la familia Pasolini a refugiarse en Casarsa, un pueblo del Friuli donde había nacido la madre. La estancia en Friuli fue muy importante para que el joven 

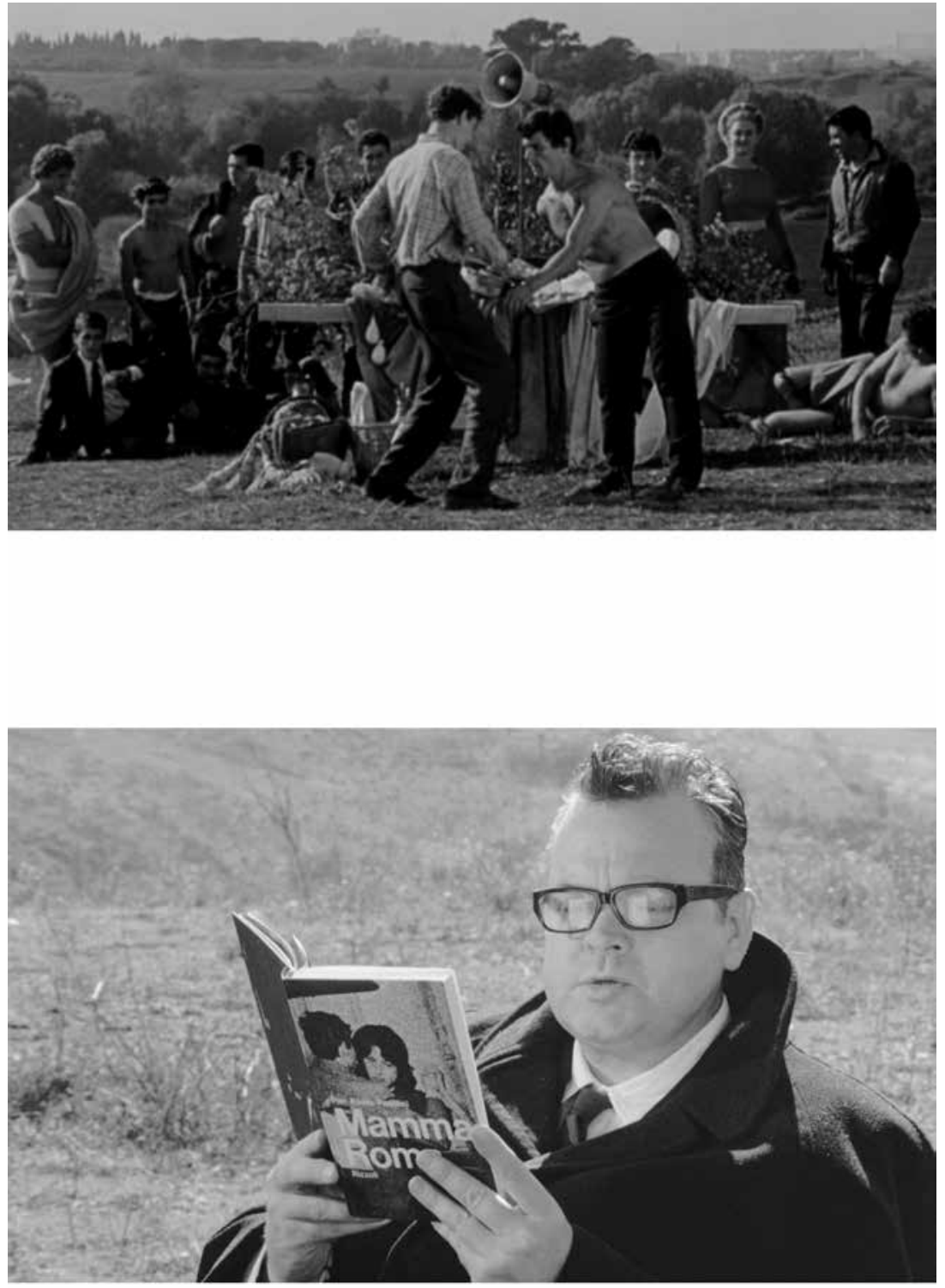

Imágenes de "La Ricotta" de Pier Paolo Pasolini, segmento de la película Ro.Go.Pa.G. (1963) 
Pasolini completara su formación con la música. En el pueblo se había refugiado una joven violinista eslovena, Pina Kalc, con la que Pier Paolo trabó una gran amistad. Fue Pina Kalc quien lo acercó a la música y le reveló a Bach, que significará para el deslumbrado Pasolini, la "música como absoluto". La música, al lado de la pintura y la poesía, será un elemento importante de su obra cinematográfica.

Durante la guerra Pasolini escribe Poesie a Casarsa en dialecto friulano, sin dejar de dibujar y pintar sobre tela cruda de saco. Nunca abandonará la pintura y dejará una notable cantidad de cuadros y retratos de amigos - Maria Callas, Laura Betti, Ninetto Davoli, Giuseppe Zigaina y otros-, entre ellos están los dibujos en carboncillo de su admirado maestro Longhi, que subrayan con afectuosa caricatura su fuerte personalidad. Por último, sus interesantes autorretratos: "El hombre con la flor en la boca" y "Autorretrato con la bufanda", de fuertes contornos, colores intensos y violentos contrastes expresionistas. Sobre su pintura, se harán los nombres de Ensor y de Munch. El pintor Giuseppe Zigaina, su amigo de siempre, después de la muerte del poeta, curará dos exposiciones de su obra figurativa, una en 1978 en el palacio Braschi de Roma (con 200 cuadros entre bosquejos, dibujos y pinturas), y otra en 1984 en la Universidad Berkeley de California, acompañada por un catálogo espléndido y reproducciones en color de toda la obra de Pasolini, publicado por la Editorial Vanni Scheiwiller de Milán, con escritos de G.C. Argán, De Micheli y Zigaina.

Los años en Casarsa fueron fecundos para Pasolini. Sin embargo, el poeta vivió su primera experiencia sexual de manera trágica. El cura al que su joven amante había confesado la relación, no respetó el secreto confesional y se armó un escándalo. Pier Paolo escribe a un amigo: "Otro en mi lugar se suicidaría; desgraciadamente yo debo vivir para mi madre”. Sufrió el alejamiento de la escuela donde enseñaba, la expulsión del Partido comunista y la ruptura con su padre. Huyó de Casarsa y con su madre se fue a Roma, pasando del mundo rural campesino del Friuli al mundo del subproletariado romano. Y nunca el poeta podrá superar el trauma de su diversidad.

No quiero afirmar que Pasolini haya sido un auténtico pintor o un autodidacta genial, ni opinar sobre el valor artístico de su producción figurativa. Pintor o no, la pintura no fue un elemento marginal, sino esen- 
cial en su obra. Lo que quiero es iluminar aspectos de su compleja personalidad, su gran creatividad, sus múltiples pasiones. Pasolini fue un fenómeno único en el mundo cultural del siglo xx italiano: pintor, poeta, narrador, literato, ensayista, periodista, dramaturgo, cineasta, actor, escenógrafo, guionista, crítico musical (escribió un largo ensayo sobre Bach), sin nunca dejar de intervenir en la vida del país con ojos críticos. Personaje incómodo y escandaloso para los italianos de derecha y de izquierda, Pasolini fue un polemista violento en sus escritos políticos, pero por naturaleza dulce, generoso: una "criatura angelical” según sus amigos que lo conocieron íntimamente.

En 1962, Pasolini escribe: "Mi gusto cinematográfico no es de origen cinematográfico sino de origen figurativo. Y no logro concebir imágenes, paisajes, composiciones de figuras afuera de esta inicial pasión pictórica". Pasolini no es el único cineasta que afirma la consanguinidad entre pintura y cine. De los italianos, Luchino Visconti recurre, en $E l$ gatopardo y Senso, a la pintura italiana del siglo XIX y Federico Fellini considera a la pintura como el verdadero "maná del cine".

Enorme fue la cultura figurativa del poeta de Casarsa, y su obra cinematográfica rica de referencias pictóricas: Giotto, Masaccio, Piero della Francesca y, del Manierismo toscano, los dos florentinos Jacobo de Pontormo y Rojo Florentino, cuya influencia encontramos en su cortometraje La Ricotta (El requesón), una pequeña obra maestra. Pasolini siente una gran afinidad con la "desesperada vitalidad" (Longhi), la "substancia agitada" de los dos florentinos, típicas de los periodos de crisis y de transmutaciones. No sé, pero lo dudo, si a la "desesperada vitalidad" de los dos misántropos florentinos puede ligarse el amor desesperado a la vida que Pasolini declara en un escrito: "Amo a la vida tan ferozmente, tan desesperadamente que para mí no puede venir nada bueno: me refiero a los datos físicos de la vida, el sol, la hierba, la juventud... y yo devoro, devoro... devoro. Cómo irá a terminar, no lo sé”. Por otro lado, Pasolini no fue un misántropo y tuvo, como se sabe, una vida social intensa, rodeado por amigos que lo amaron.

Federico Zeri, otro de los grandes historiadores del arte del siglo XX al lado de Roberto Longhi, subraya la fuerte afinidad entre Pasolini y el pintor Caravaggio (Michelangelo Merisi), supuestamente homosexual. El pintor milanés introdujo en su pintura un mundo humano fuera de 
los cánones del clasicismo, el mundo plebeyo de los bajos fondos urbanos: prostitutas, marginados, rufianes, pobres, sucios y andrajosos a los que tomó de modelos para sus santos y madonas. Su compasión por los desheredados que viven en la miseria y al margen de la sociedad, es la misma que Pasolini siente por el subproletariado de las barriadas de la periferia romana (ya presente en su narrativa).

El acercamiento, del todo atinado, de Pasolini a Caravaggio (sobre quien el poeta escribió un ensayo) no excluye la influencia decisiva que Pontorno y Rojo Florentino tuvieron en el poeta de Casarsa. Y me voy a detener en el cortometraje La ricotta (El requesón), episodio de una película colectiva -Ro.Go.Pa.G. - dirigida por Rossellini, Godard, Pasolini y Gregoretti. Episodio magistral, La ricotta se abre con un estupendo twist bailado por dos gallardos jóvenes que figuran en el reparto. En el cortometraje, que mantiene un ritmo frenético hasta el final, Pasolini recurre alegremente y para el regocijo del espectador a las viejas técnicas del cine mudo, sobre todo del amado "Charlot"-Chaplin.

La ricotta es la representación popular y, por lo tanto, no ortodoxa y en clave paródica de la Pasión de Cristo, donde lo profano y lo sagrado, lo cómico y lo trágico, las blasfemias, los insultos, las vulgares carcajadas, los bailes desenfrenados y el strip-tease de una comparsa en el papel de santa, se entremezclan: una mezcolanza que no es una novedad, porque la vemos en muchas celebraciones populares.

El reparto no está compuesto por actores profesionales, sino por los subproletarios de los barrios romanos. El personaje principal de La ricotta es el bondadoso, generoso y religioso Stracci (harapos) que tiene en la escena de la Crucifixión el papel del buen ladrón. Stracci vive en la miseria de los barrios romanos, agobiado por un hambre atávica —en todo el cortometraje domina el hambre-, no obstante la presencia de mesas puestas, ricas de flores y frutas que nos recuerdan a los bodegones de Caravaggio. Después de varios trances, vemos a Stracci vender a su perrito y correr a comprarse una enorme rebanada de requesón que va a devorar compulsivamente en la gruta donde acostumbra refugiarse, acompañado por las carcajadas de sus compañeros, espectadores divertidos que le ofrecen más y más comida que él devora, nunca saciado, hasta que lo llaman al set. 
La intención fundamental [escribirá Pasolini] era representar, al lado de la religiosidad de Stracci, la carcajada vulgar, irónica, cínica, incrédula del mundo contemporáneo. [...] Pienso en una representación sagrada del siglo xIv, en la atmósfera sacra e inspirada en quien la representaba y en quien asistía, y no puedo no pensar con indignación, con dolor, con nostalgia, en los aspectos tan atrozmente diversos del mundo moderno.

La ricotta será secuestrada y procesada por vilipendio a la religión de Estado, no obstante, el prólogo del filme de Pasolini: "La historia de la Pasión es la más grande que yo conozca, y los textos que la narran los más sublimes que nunca hayan sido escritos".

El acompañamiento de la música es otro elemento importante en todo el cine de Pasolini, así en La ricotta como en L'accattone y en El Evangelio según San Mateo. En estos dos últimos la música sacra, principalmente de Bach, y la música clásica - Prokofiev, Vivaldi...se alternan con la popular (la Missa Luba congolesa, por ejemplo, que es una versión de la misa católica, basada en la tradición musical del Congo), y cantos espirituales negros, bajo el signo de la "contaminación", como dice Pasolini: una mezcolanza de estilos, un pastiche; al igual que en su narrativa la mezcla del lenguaje literario y la jerga romanesca. Interesante notar la disonancia entre imagen y música: la música sacra de Bach que acompaña las escenas de degradación y riñas en L'Accattone (rufián que vive de expedientes, de su mujer y de pequeños hurtos); una música que sacraliza la vida violenta de sus protagonistas, víctimas y victimarios (a algo similar recurre Buñuel al final de Viridia$n a$, acompañado por el Aleluya de Handel). Y precisamente a propósito de L'Accattone, Pasolini habla de la contaminación entre la fealdad y la violencia de la situación y lo sublime de la música, una amalgama de lo alto y lo bajo, de lo sublime y lo cómico, propia del realismo occidental, del que habla Erich Auerbach en Mimesis, libro muy amado por el poeta.

La Crucifixión de Jesús es la escena central de La ricotta: un tableau vivant inspirado en los retablos de la Deposición de Jacopo de Pontormo - el Descenso de la Cruz de Jesús- $(313$ x 192 cm, Iglesia de Santa Felicita, Florencia) y de Rosso Fiorentino (375 x $196 \mathrm{~cm}$, Pinacoteca di Volterra), composiciones abigarradas y angulosas de intenso dramatismo 

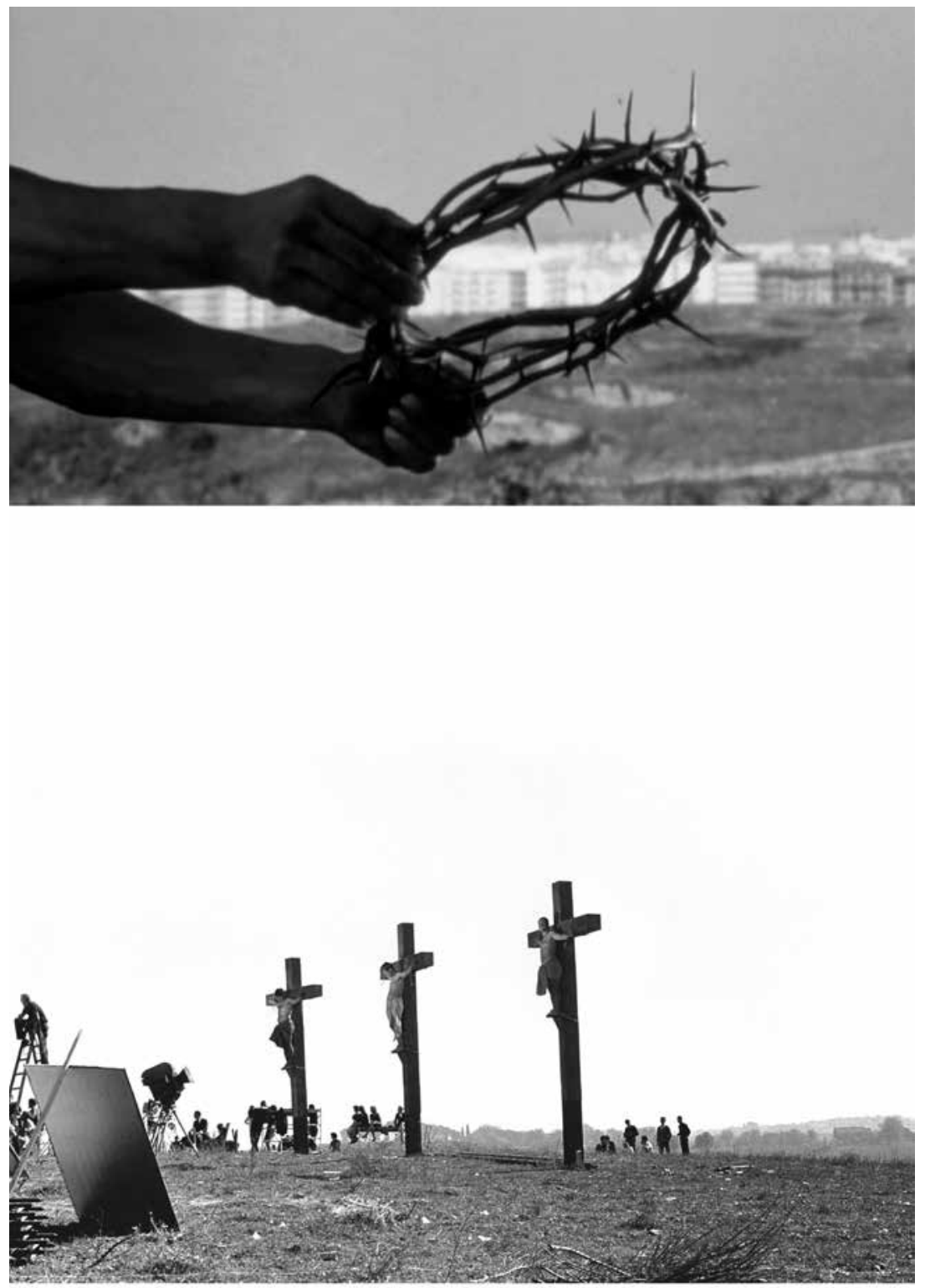

Imágenes de "La Ricotta" de Pier Paolo Pasolini, segmento de la película Ro.Go.Pa.G. (1963) 
en el retablo de Rojo Florentino; de colores pálidos, exangües las figuras desproporcionadas y alargadas de Pontormo, bajo la influencia de Durero, que suscitó las críticas de Vasari, no obstante que Miguel Ángel haya sido la figura predominante en Pontormo. Como fondo musical de la Crucifixión Pasolini alterna la "Sinfonía de la cantata profana" de Alessandro Scarlatti, y la secuencia Dies irae de Tomás de Celano, pero tocada por un instrumento popular, el acordeón: como siempre, mezcla de lo culto y de lo popular. Imágenes y música se acompañan con los conmovedores versos de la lauda Donna de Paraiso de Jacopone da Todi, el lamento fúnebre de María que llora a los pies de la cruz:

Hijo, el alma te ha dejado, / hijo de la extraviada, / hijo de la desaparecida, /ihijo atosigado! / Hijo blanco y bermejo / hijo sin igual / hijo, ¿en quién me apoyo? / ¡Hijo, me has abandonado!² (La traducción es mía).

Esta escena alcanza el fuerte dramatismo de los retablos de Pontormo y me parece que lo supera, porque el oído - música y poesía que acompañan la escena - intensifica la imagen. La pasión se cumple con el apacible, bueno "como el pan", generoso, y siempre "muerto de hambre" Stracci quien muere en la cruz — isuprema ironía! — de indigestión. La Ricotta, así como L'Accattone, son la metáfora del sufrimiento del desheredado subproletariado romano.

En La ricotta Pasolini no renuncia a su acostumbrado discurso político, a su crítica feroz del pueblo italiano a través de Orson Welles en el papel de director de la película, un mofador y despreciativo Welles, doblado por la estupenda voz de Giorgio Bassani. Son los temas que el incómodo Pasolini debate al mismo tiempo en la prensa y que suscitan la ira de la derecha y, también, la irritación de la izquierda. Al mediocre periodista que viene a entrevistarlo y le pregunta qué piensa del pueblo italiano, Welles contesta, cortante: el pueblo más analfabeta y la burguesía más ignorante de Europa. Después de esta feroz requisitoria Welles lee el estupendo poema Io sono una forza del passato, de Pasolini:

${ }^{2}$ Figlio, l'alma t'è scita, / figlio de la smarrita, / figlio de la sparita, / figlio attossecato! /// Figlio bianco e vermiglio, / figlio senza simiglio / figlio a cui m'apiglio? / Figlio, pur m'ai lassato! 
Yo soy una fuerza del pasado. / Sólo en la tradición radica mi amor. / Vengo de las ruinas, de las Iglesias, / de los retablos, de los burgos / olvidados en los Apeninos y los Pre Alpes, / donde han vivido los hermanos. / Vago por la Tuscolana como un loco, / por la Apia como un perro sin dueño. / O miro los crepúsculos, las mañanas / sobre Roma, sobre la Ciociaria, sobre el mundo, / como los primeros actos después la Posthistoria / con la que existo, por privilegio de registro civil, / del punto extremo de alguna edad / sepultada. Monstruoso es quien nació / de las entrañas de una madre muerta. / Y yo, feto adulto, vago / más moderno de todo moderno / a buscar a los hermanos que ya no están ${ }^{3}$ (La traducción es mía).

Encontramos en estos versos al auténtico Pasolini, poeta de la tradición y de la Italia del pasado, cuando - como dice Alberto Moraviaéste era el país del Hombre, en toda su humanidad, mientras que la Italia de hoy se ha vuelto el país del mediocre hombre medio (y es notorio el desprecio de Pasolini hacia el hombre medio).

Poeta cívico y anticlerical, en Pasolini sobreviven dos mil años de cristianismo: "Con mis ancestros [escribe] he construido las iglesias románicas, y después las iglesias góticas, y después las iglesias barrocas, que son mi patrimonio, en su contenido y estilo. Sería un loco si negara esta fuerza potente que está dentro de mí...". Y el vínculo con la tradición, su "re-visitación" de la tradición artística italiana desde Giotto hasta el Renacimiento y el Manierismo, está presente en toda la obra de Pasolini, así como su búsqueda desesperada de los "Hermanos que ya no están".

Annunziata Rossi

arpapisca@gmail.com

${ }^{3}$ Io sono una forza del passato / Solo nella tradizione è il mio amore. / Vengo dai ruderi, dalle chiese, / dalle Pale d'altare, dai borghi / dimenticati sugli Appennini e le Prealpi, / dove sono vissuti i fratelli. / Giro per la Tuscolana come un pazzo, / per l'Appia come un cane senza padrone. / O guardo i crepuscoli, le mattine / su Roma, sulla Ciociaria, sul mondo, / come i primi atti della Dopostoria, / cui io sussisto, per privilegio d'anagrafe, / dall'orlo estremo di qualche età / sepolta. Mostruoso è chi è nato / dalle viscere di una donna morta. / E io, feto adulto, mi aggiro / piu moderno d'ogni moderno / a cercare i fratelli che non sono più. 